\title{
Reproductive Characteristics of Redberry Juniper
}

\author{
MICHAEL A. SMITH, HENRY A. WRIGHT, AND JOSEPH L. \\ SCHUSTER
}

Highlight: $A$ relatively high moisture level $(0$ to $4 \mathrm{~atm})$ and a relatively low temperature $\left(18^{\circ} \mathrm{C}\right)$ were found to be most favorable for germination of redberry juniper (Juniperus pinchoti) seeds. Shallow planting depths $(0$ to $2 \mathrm{~cm})$ favored seedling emergence. Seed germination was not affected appreciably by passage through animals. Cutting of seedling tops above the axils of the cotyledons allowed 58\% survival, while cutting 1- to 12-year-old plants at ground line, which removed the meristematic stem tissue, produced $99 \%$ mortality. Moderate and heavy blue grama (Bouteloua gracilis) competition severely limited redberry juniper seedling growth compared to no competition. It severely reduced shoot length, root leng th, number of shoot and root branches, and plant dry weight. These results indicated that the maintenance of a good grass cover coupled with a top removal agent such as fire or cutting at ground level will prevent encroachment of redberry juniper, a resprouting species, on grassland.

Redberry juniper (Juniperus pinchoti), an evergreen conifer, occurs primarily in western Texas, Oklahoma, New Mexico, and Arizona. Despite the large areas infested with this resprouting species, its reproductive characteristics have not been studied in detail. This study was designed to determine the optimum moisture and temperature levels for seed germination, optimum planting depth for seedling establishment, influence of passage of seeds through animals on germination, age of seedling capable of resprouting, and the effect of grass competition on seedling establishment and development.

Autecological studies have not been conducted on redberry juniper, but they have been conducted on other species. Johnsen (1962) found that one-seed juniper (Juniperus monosperma) germinated best in continually moist (35\% moisture) soil and that no germination occurred in alternately wet and dry soil. He also found that juniper seeds germinated best between $17^{\circ} \mathrm{C}$ and $32^{\circ} \mathrm{C}$. Germination was significantly lower at $7^{\circ} \mathrm{C}$. The best seed depth for germination and emergence was less than $2.5 \mathrm{~cm}$.

Many researchers (Emerson, 1932; Driscoll, 1964; Wight and Fisser, 1968; and Burkhardt and Tisdale, 1969) concluded that competition reduced the survival and invasion of juniper

At the time of the research, authors were research assistant and professors of range management, Texas Tech University, Lubbock. At present Michael Smith is research assistant, Department of Range Science, Utah State University, Logan; Joseph Schuster is professor and head, Department of Range Science, Texas A\&M University, College Station.

The research is College of Agricultural Sciences Contribution Number T-9-1 35, Texas Tech University, Lubbock.

Manuscript received March 9, 1974. seedlings on grasslands. This point was further substantiated by other researchers (Cottam and Stewart, 1940; and Allred, 1949) who found that the removal of grass competition by grazing, erosion, or breaking of the sod will accelerate the invasion of juniper. Nevertheless, Johnsen (1962) and Arnold et al. (1964) found that in years of above normal moisture, seedling juniper trees may become established in even the best stands of grass. Wells (1965) hypothesized that recurrent fires probably kept young juniper trees out of good stands of grass and restricted them to scarps with shallow soils.

\section{Methods}

$\Lambda$ field investigation of redberry juniper resprouting characteristics was conducted on the Post-Montgomery Estate Ranch in Garza County, Texas. All other phases of this study were conducted in laboratories and greenhouses.

The seeds used were collected in January, 1971, approximately $4.8 \mathrm{~km}$ southwest of Post, Texas, in Garza County. One collection included seeds from scats of small mammals, probably coyote, fox, or raccoon found throughout the redbcrry juniper-infested area. Another seed sample was collected from six mature trees about $2.5 \mathrm{~m}$ tall and $3.5 \mathrm{~m}$ in crown diameter. Seeds were stored in moist sand at $1^{\circ} \mathrm{C}$ and used (unscarified) as needed during the following year beginning in June, 1971.

Moisture level and air temperature effects on germination of redberry juniper seeds were evaluated using solutions of distilled water and carbowax 4000 (polethylene glycol) of 0 , $2,4,8$, and 16 bars osmotic potential and constant air temperatures of 10,18 , and $27^{\circ} \mathrm{C}$ in all possible combinations. At each moisture level, 36 seeds were placed in $11 \mathrm{~cm}$ petri dishes and germinated in controlled environmental chambers maintained at 10,18 , or $27^{\circ} \mathrm{C}$ for 60 days. Each petri dish was considered a replication. Petri dishes were arranged in a completely randomized design with three replications. Number of seeds germinating and overall seedling elongation were recorded as they occurred during the course of the 60- and 72-day trials of the experiment. In addition to the constant temperature data, seeds were germinated at $0,2,4,8$, and 16 bars osmotic potential under alternating $8 \mathrm{hr}$ day $\left(27^{\circ} \mathrm{C}\right)$ and $16 \mathrm{hr}$ night $\left(10^{\circ} \mathrm{C}\right)$ temperatures. Five replications with 20 seeds per petri dish were used for each osmotic potential.

Optimum planting depth was determined by planting 46 seeds at the soil surface and at $0.5 \mathrm{~cm}$ increments to a depth of $6 \mathrm{~cm}$. Each treatment was replicated three times in containers with 3 liters of soil. The containers were maintained under greenhouse conditions with a diurnal temperature range of 16 to $27^{\circ} \mathrm{C}$. The soil was kept continually moist for 210 days. Numbers of seedlings emerging were recorded during the course of the experiment. 
The ability of seedlings to survive following top removal and the morphological source of sprouts were determined by removing the tops of seedlings $1 \mathrm{~mm}$ above the axil of the cotyledons at 7-day intervals to 56 days under greenhouse conditions. After 45 days they were noted as dead or alive.

To evaluate the response of juvenile redberry junipers to top removal in the field, plants from current year's seedlings to 12 years old were cut at ground level (usually below the bud zone). A minimum of five trees, except for the 9,10 , and 11 year-old groups (four, four and two trees respectively) were marked, and the tops were removed in each age group in July. Plants were evaluated for survival in late September by noting any evidence of living tissue in the root crown. Bark was peeled back and visual determinations were made.

Germination of seeds which had passed through animals and those which had not been ingested was determined in 13 replications of 50 seeds using distilled water on filter paper in $11-\mathrm{cm}$ petri dishes. Number of seeds germinating was recorded as it occurred during the course of the 70-day trial.

Seedling redberry junipers were grown in three levels of grass competition under greenhouse conditions in wooden boxes $720 \mathrm{~cm}^{2} \times 30 \mathrm{~cm}$ deep. Blue grama (Bouteloua gracilis) was seeded and thinned to 0,16 , or 32 plants per box. Redberry juniper seeds (100/box) were planted 2 months after the blue grama seeds had germinated. After redberry seedling emergence, the containers with 16 blue grama plants were kept clipped to a $10 \mathrm{~cm}$ height to simulate a moderate level of blue grama biomass. Data recorded at the termination of the study included redberry juniper seedling weight, root and top lengths, and number of branches on roots and tops.

Analysis of variance or Chi-square analyses were used to test for differences between treatments (Cochran and Cox, 1957; Snedecor and Cochran, 1967).

\section{Results and Discussion}

\section{Moisture Level and Temperature Effects}

The interaction between moisture level and temperature effects on germination of redberry juniper seeds was not significant. However, moisture level and temperature independently affected germination. Seedling germination declined steadily as available moisture declined (Table 1).

Temperature produced greater germination and seedling emergence in the mid range of the temperatures tested $(P<$ 0.05 ). The optimum soil temperature (among those tested) for germination and emergence was $18^{\circ} \mathrm{C}$. There was no emergence at $10^{\circ} \mathrm{C}$, and very limited germination and emergence at $27^{\circ} \mathrm{C}$. Average emergence was $0.0,1.2$, and 0.2 seedlings per replication at 10,18 , and $27^{\circ} \mathrm{C}$, respectively.

Optimum germination at $18^{\circ} \mathrm{C}$ and optimum moisture levels of 0 to 4 atm suggest that mild, moist climatic conditions are required for germination of redberry juniper. Thus, germination would be limited to fall or spring when moisture conditions would promote seedling growth and favor establishment.

Table 1. Germination (number) and emergence (number) of redberry juniper seeds at five levels of osmotic potential. ${ }^{1}$

\begin{tabular}{lcrcccc}
\hline & \multicolumn{5}{c}{ Osmotic potential (bars) } \\
\cline { 2 - 6 } Measurement & 0 & 2 & 4 & 8 & 16 \\
\hline Seeds germinating & $15 \mathrm{a}$ & $11 \mathrm{a}$ & $7 \mathrm{ab}$ & $1 \mathrm{bc}$ & $0 \mathrm{c}$ \\
Seedlings elongating & $13 \mathrm{a}$ & $8 \mathrm{a}$ & $6 \mathrm{a}$ & $0 \mathrm{a}$ & $0 \mathrm{a}$ \\
\hline
\end{tabular}

${ }^{1}$ Values in rows followed by the same letter are not significantly different at the .05 level of probability. Each number is based on 100 seeds.
Table 2. Survival of redberry juniper seedlings having epicotyl removed 1 to 56 days after emergence and of intact plants.

\begin{tabular}{lrrrrrrrrrr}
\hline & \multicolumn{8}{c}{ Days after emergence } & \\
\cline { 2 - 10 } Measurement & 1 & 7 & 14 & 21 & 28 & 35 & 42 & 49 & 56 & Control \\
\hline Number of seedlings & 16 & 38 & 17 & 13 & 17 & 18 & 15 & 18 & 25 & $0^{1}$ \\
Seedlings surviving & 6 & 25 & 3 & 4 & 7 & 10 & 4 & 4 & 12 & 177 \\
$\quad \begin{array}{l}\text { Number } \\
\quad \text { Percent }\end{array}$ & 38 & 66 & 18 & 31 & 41 & 55 & 27 & 22 & 48 & 80 \\
\hline
\end{tabular}

${ }^{1} 220$ intact plants used for control.

\section{Optimum Planting Depth}

No seedlings emerged from depths greater than $2 \mathrm{~cm}$, but 4 , $1,2,0$, and 1 seedling emerged at $0, .5,1,1.5$, and $2 \mathrm{~cm}$, respectively. Differences between the 0 to $2 \mathrm{~cm}$ depths of planting were not significant, but emergence at these depths was significantly greater than at the 2.5 to $6 \mathrm{~cm}$ depths $(P<$ $0.05)$. The shallow depths required for seedling emergence in this study support the postulated need for extended periods of high soil moisture levels in the field and could also indicate the need for a diurnal temperature and light fluctuation, as these conditions were present in the greenhouse during the study.

\section{Resprouting after Top Removal}

Mortality was 58\% among 177 seedlings cut $1 \cdot \mathrm{mm}$ above the axil of the cotyledon and $20 \%$ among intact controls. Survival was similar regardless of time of cutting up to 56 days after emergence (Table 2). The resprouting was concentrated in the axil of the cotyledons. In no case were resprouts found below the cotyledons. This indicated that redberry junipers were stem sprouters and not root sprouters and that they would be killed if all meristematic stem tissues were removed. The field study involving top removal of seedling and juvenile junipers was initiated to confirm this possibility. The ability of naturally occurring secdling and juvenile redberry junipers to resprout following top removal at ground level was quite limited. When cutting occurred at ground level, resprouting occurred only in the 8- and 12-year-old groups (30 and 14\%, respectively) even though $40.6 \mathrm{~cm}$ of rain fell on the study area from July through September, and growing conditions were near optimum. In some instances the cotyledonary zone of the 8-and 12-year-old trees was covered by soil.

Top removal at ground level in most cases removed the zone of resprouting which coincides with the axil of the cotyledons in very young plants. The zone of resprouting was obviously in the stem and above the root crown in these age groups. This stem sprouting characteristic and apparent lack of root crown sprouting would indicate that redberry juniper is susceptible to control by any agent such as fire, insects, chemicals or cutting which kills the stem above the root crown. The position of the sprouting zone in the early years of growth, and the absence of sprouts from below this zone, should leave seedling and juvenile trees susceptible to fire damage for at least 12 years. This corroborates the postulation by Ellis and Schuster (1968) that fire was one factor preventing this species from encroaching onto grasslands before wildfires were brought under control. That resprouting after top removal in the field occurred only in the older age groups ( 8 and 12 year-old) would indicate that fires may need to occur only at intervals of 8 to 12 years to suppress juniper establishment in grasslands. 
Table 3. Growth of juniper seedlings when subjected to three degrees of competition from blue grama. ${ }^{1}$

\begin{tabular}{lccccc} 
& \multicolumn{5}{c}{ Growth characteristics } \\
\cline { 2 - 6 } $\begin{array}{l}\text { Degree of } \\
\text { competition }\end{array}$ & $\begin{array}{c}\text { Shoot } \\
\text { length } \\
(\mathrm{cm})\end{array}$ & $\begin{array}{c}\text { Root } \\
\text { length } \\
(\mathrm{cm})\end{array}$ & $\begin{array}{c}\text { Number } \\
\text { of stem } \\
\text { branches }\end{array}$ & $\begin{array}{c}\text { Number } \\
\text { of root } \\
\text { branches }\end{array}$ & $\begin{array}{c}\text { Dry } \\
\text { weight } \\
(\mathrm{g} / \mathrm{plant})\end{array}$ \\
\hline Heavy (32 plants) & $6.7 \mathrm{a}$ & $23.1 \mathrm{a}$ & $0.0 \mathrm{a}$ & $4.0 \mathrm{a}$ & $0.05 \mathrm{a}$ \\
Moderate (16 plants) & $6.8 \mathrm{a}$ & $28.7 \mathrm{a}$ & $0.4 \mathrm{a}$ & $7.4 \mathrm{a}$ & $0.07 \mathrm{a}$ \\
None (0 plants) & $31.8 \mathrm{~b}$ & $97.3 \mathrm{~b}$ & $28.7 \mathrm{~b}$ & $51.3 \mathrm{~b}$ & $4.72 \mathrm{~b}$ \\
\hline
\end{tabular}

"Means in columns followed by the same letter are not significantly different at the .05 level of probability. Most boxes contained two to three juniper plants; none contained more than six juniper plants.

\section{Germination of Seeds Ingested by Animals}

No significant differences in germination existed between redberry juniper seeds which had passed through small mammals and those which had not been ingested $(P<0.05)$. Germination was $5 \%$ and $5.98 \%$. This suggests that seed passage through small animals does not scarify the thick seed coat. Evidently the role of mammals in redberry juniper reproduction is primarily that of dispersing seed.

\section{Effect of Grass Competition on Seedling Growth}

Redberry juniper seedling growth was severely retarded by competition from blue grama compared to no competition (Table 3). No differences existed in seedling growth between the two levels of blue grama grass (16 and 32 plants/container) competition. This lack of difference was attributed primarily to the extensive root systems of blue grama in both treatments, regardless of the number of plants or the $10-\mathrm{cm}$ clipping treatment. Intraspecific competition was not an obvious factor affecting juniper growth due to the low density of juniper plants. Lack of differences between the moderate and heavy competition treatments indicate that moderate livestock grazing probably would not enhance the establishment of juniper seedlings.

The most striking evidence of the high vigor of seedlings with no competition was the proliferation of stem and root branches (Fig. 1). The branching and height of these seedlings contrasted sharply with the short stature and almost total absence of branching on the seedlings grown with heavy and moderate competition. Shading from the grass, particularly in the heavy competition treatment, probably reduced the juniper growth.

The small size and low vigor of the seedlings grown with competition leaves them susceptible to two natural agents which could prevent their establishment in grasslands. They would be susceptible to drouth because of their limited root systems and to grass fires because of their stature and small stem size.

These findings plus the indication that extended periods of favorable moisture conditions are required for germination and seedling emergence of juniper indicate that juniper encroachment is unlikely to occur on well managed grasslands in semiarid conditions. Range management programs which maintain a good grass cover should inhibit the spread of redberry juniper.

\section{Literature Cited}

Allred, B. W. 1949. Distribution and control of several woody plants in

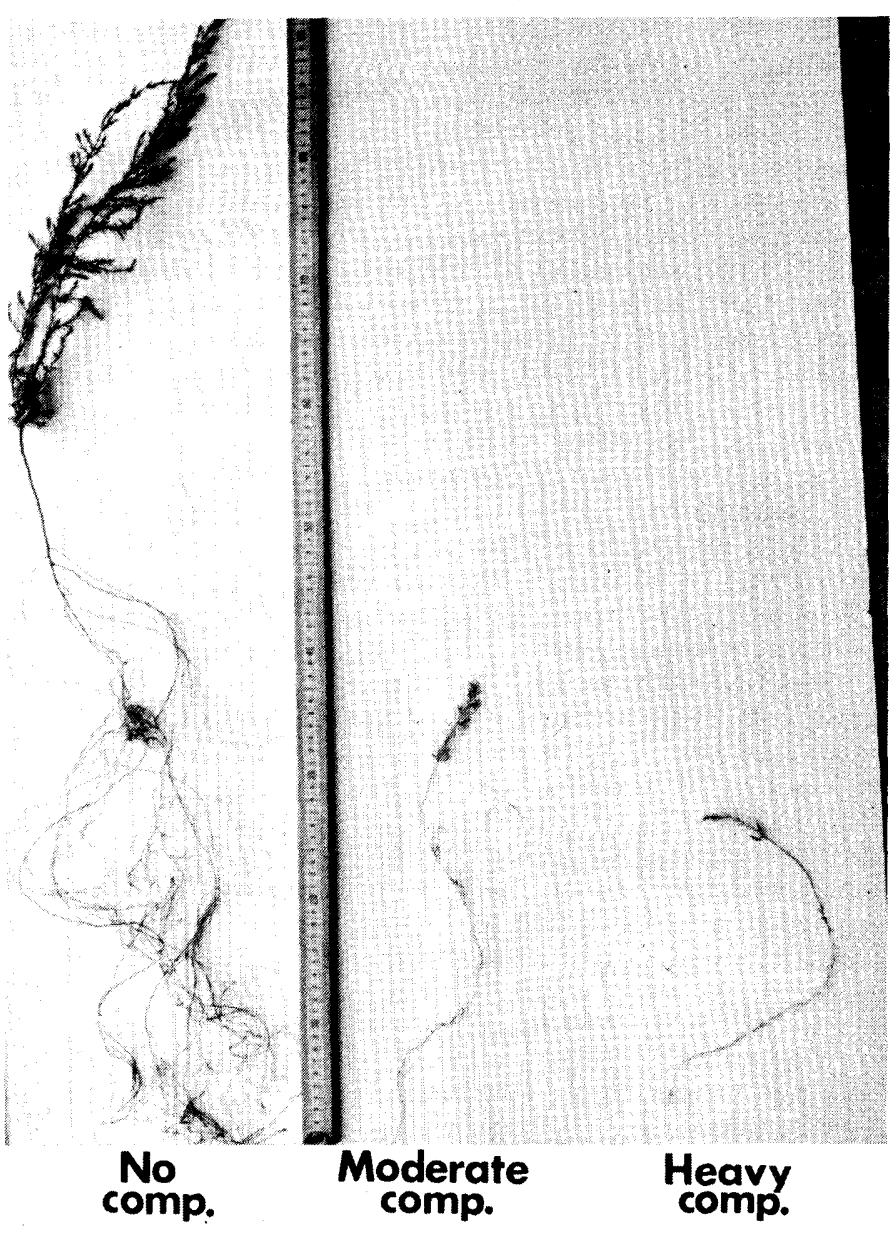

Fig. 1. Roots and shoots of redberry juniper seedlings grown under zero, moderate, and heavy blue grama grass competition.

Texas and Oklahoma. J. Range Manage. 2:17-29.

Arnold, J. F., D. A. Jameson, and E. H. Reid. 1964. The pinyon-juniper type of Arizona: effects of grazing, fire, and tree control. Forest Service, U.S. Dep. of Agr., Prod. Res. Rep. 84. 28 p.

Burkhardt, J., and E. W. Tisdale. 1969. Nature and successional status of western juniper vegetation in Idaho. J. Range Manage. 22:264-270.

Cochran, W. G., and G. M. Cox. 1957. Experimental designs. Second ed., John Wiley and Sons. New York. 611 p.

Cottam, W. P., and G. Stewart. 1940. Plant succession as a result of grazing and of meadow desiccation by erosion since settlement in 1862. J. Forest. 38:613-626.

Driscoll, R. S. 1964. A relict area in the central Oregon juniper zone. Ecology 45:345-353.

Ellis, D., and J. L. Schuster. 1968. Juniper agc and distribution on an isolated butte in Garza County, Texas. The Southwestern Nat. 13:343-348.

Emerson, F. W. 1932. The tension zone between the grama grass and pinyon-juniper associations in northeastern New Mexico. Ecology 13:347-358.

Johnsen, T. N., Jr. 1962. One-seed juniper invasion of northern Arizona grasslands. Ecol. Monogr. 32:187-207.

Snedecor, G. W., and W. C. Cochran. 1967. Statistical methods. Sixth ed., Iowa State Univ. Press, Ames. 593 p.

Wells, P. W. 1965. Scarp woodlands, transported grassland soils and concept of grassland climate in the Great Plains region. Science 148:246-249.

Wight, J. R., and H. G. Fisser. 1968. Juniperus osteosperma in northwestern Wyoming, their distribution and ecology. Univ. Wyo. Agr. Exp. Sta. Sci. Monogr. 7. 31 p. 